TEME, г. XLIII, бр. 2, април - јун 2019, стр. 581-598

Прегледни рад

https://doi.org/10.22190/TEME171017035P

Примљено: 17. 10. 2017.

UDK 340.6:341.231.14

Ревидирана верзија: 9. 12. 2018.

Одобрено за штампу: 12. 4. 2019.

\title{
НЕКИ АСПЕКТИ ПРАВА НА СУДСКУ ЗАШТИТУ ЛИЦА \\ СА МЕНТАЛНИМ СМЕТЊАМА У ПОСТУПКУ ЛИШЕЊА ПОСЛОВНЕ СПОСОБНОСТИ - ПРАКСА ЕВРОПСКОГ СУДА ЗА ЉУДСКА ПРАВА
}

\author{
Душица Палачковић ${ }^{1}$, Санда һорац ${ }^{2 *}$ \\ ${ }^{1}$ Универзитет у Крагујевцу, Правни факултет, Крагујевац, Србија \\ ${ }^{2}$ Ниш, Србија \\ *advokatsandacorac@gmail.com
}

\begin{abstract}
Апстракт
У раду су анализирани поједини значајни аспекти процесноправног положаја особа са менталним сметњама у поступку лишења пословне способности. Без обзира на нормативни оквир, међународни и национални, посебно Конвенцију УН о правима особа са инвалидитетом, који признаје и штити права ове осетљиве друштвене групе, значајан број предмета пред Европским судом за људска права и одлука у којима се државе проглашавају одговорним указује на постојање и проблема њиховог процесноправног положаја. Они су условљени (не)примењивањем процесних гаранција које пружа чл. 6 Европске конвениије о заштити људских права и основних слобода, односно право на правично суђење. Наиме, особености лица са менталним сметњама узрокују и посебности у примени права на правично суђење у судским поступцима у које су ова лица укључена. Због тога би се могло говорити о формулисаним специфичним стандардима којима се, суштински, разрађује један од кључних појмова Конвенције УН о правима особа са инвалидитетом - „разумно прилагођавање”, као и о директној вези са потребом специфичне примене поменутог члана 6 Европске конвенције. Стандарди који следе из примене члана 6 бројни су и анализирање свих са аспекта заштите права лица са менталним сметњама није било могуће у раду овог обима, па је, стога, посебна пажња поклоњена праву ових лица да покрену и воде поступак лишења пословне способности, њиховом личном учешћу у том поступку и заступању.
\end{abstract}

Кључне речи: лица са менталним сметњама, поступак за лишење пословне способности, право на судску заштиту лица са менталним сметњама. 


\title{
SOME ASPECTS OF RIGHT ON JUDICIAL PROTECTION OF PERSONS WITH MENTAL DISIBILITIES IN THE PROCEDURES FOR DEPRIVATION OF LEGAL CAPACITY - PRACTICE OF THE EUROPEAN COURT OF HUMAN RIGHTS
}

\begin{abstract}
The paper analyzes certain important aspects of the procedural position of persons with mental disabilities in the procedures for deprivation of legal capacity. Regardless of the normative framework, both international and national, particularly the UN Convention on the Rights of Persons with Disabilities, which largely protects the rights of this sensitive group of people, a significant number of cases before the European Court of Human Rights and decisions in which Contracting States are declared responsible indicate that there is a problem of their procedural position. They are principally conditioned by applying (or not applying) the procedural safeguards provided by Article 6 of the European Convention for the Protection of Human Rights and Fundamental Freedoms, or the right to a fair trial. Namely, the special features of persons with mental disabilities also cause the particularities in the application of the right to a fair trial in the court procedures in which these persons are involved. Therefore, we could talk about formulated specific standards that essentially elaborate one of the key concepts of the UN Convention on the Rights of Persons with Disabilities - "reasonable adaptation", as well as a direct link to the need for a specific application of the already mentioned Article 6 of the European Convention. The standards that follow from the application of Article 6 are numerous and the analysis of all from the aspect of protecting the rights of persons with mental disabilities is not possible in the paper of this volume, and therefore, special attention was given to the right of these persons to initiate and conduct the procedures for deprivation of legal capacity, personal participation and representation in that procedures.
\end{abstract}

Key words: persons with mental disabilities, procedure for deprivation of legal capacity, right to judicial protection of persons with mental disabilities.

\section{УВОД}

Лица са инвалидитетом убрајају се у категорију посебно осетљивих друштвених група (друштвено рањиве особе, енгл. socially vulnerable persons). Иако је постигнута начелна сагласност да је инвалидитет предмет људских права (World Health Organization, 2011), највећи број општих и посебних уговора о људским правима не регулише изричито положај лица са инвалидитетом, већ се о томе посредно закључује. Посебна заштита ових лица гарантована је $\mathrm{KoH}$ вениијом о правима особа са инвалидитетом, ${ }^{1}$ која у ову категорију

\footnotetext{
${ }^{1}$ Конвенција о правима особа са инвалидитетом, Резолуција Генералне скупштине УН A/RES/61/106, 2006 („Конвенција УН”) јесте правно обавезујући међународни инструмент који садржи исцрпну листу права ових лица. Ратифика-
} 
укључује све који имају дугорочна физичка, ментална, интелектуална или чулна оштећења која у интеракцији са различитим препрекама могу ометати њихово пуно и ефикасно учешће у друштву на једнакој основи са другима (Конвениија УН, чл. 1, ст. 2).

За остварење права на судску заштиту лица са менталним сметњама од посебног значаја је чл. 12 Конвенције УН, који се односи на равноправност пред законом, односно који признаје право овим лицима „да свуда буду призната пред законом, као и друга лица” (ст. 1), односно „да остварују свој правни капацитет равноправно са другима у свим аспектима живота" (ст. 2). Конкретније, о равноправном „приступу правди” ових лица говори чл. 13 Конвенције УН, који се мора обезбедити „у складу са процедуром и старошћу”, а у циљу „олакшања ефикасног обављања дужности директних и индиректних учесника, као и улоге сведока, у свим судским поступцима" (ст. 1). У основи, проблем се своди на неопходност разликовања пословне и менталне способности. Општи коментар чл. 12 Конвенције УН пословну способност дефинише као „могућност једног лица да буде носилац права и обавеза (правна способност - legal standing) и да користи ова права и обавезе (правно деловање - legal agency)", сматрајући је кључном за постизање суштинског учешћа у друштву, док се ментална способност односи на „вештине доношења одлуке, које природно варирају од особе до особе и могу бити различите за дату особу у зависности од многих фактора, укључујући факторе средине и друштвене факторе" (Општи коментар, 2014, пар. 12). Суштински проблем није правна способност лица са менталним сметњама, већ њихова пословна, а онда и процесна пословна способност стога што је друга условљена првом. ${ }^{2}$ Како би се лица са инвалидитетом, посебно менталним, ${ }^{3}$ прихватила као „субјекти” права, носиоци овлашћења која их чине правним субјектима једнаким осталим лицима (Kos, 2014, str. 217), Комитет за права особа са инвалидитетом УН-а („Комитет”) у Општем коментару инсистира на укидању праксе, коју потврђује већина извештаја држава уговорница,

цијом Конвеницје УН и Опциионог протокола уз њу, ови значајни међународни акти постали су део правног система Републике Србије (Закон о потврђивағу Конвенције о правима особа са инвалидитетом, Службени гласник РС - Међународни уговори, бр. 42 (2009)).

2 Закон о парничном поступку РC, 2011, чл. 75, ст. 1 и 2 прописује да потпуно пословно способна странка може сама да предузима радње у поступку (парнична способност као вид процесне пословне способности) и да је пунолетно лице коме је ограничена пословна способност парнично способно у границама своје пословне способности.

${ }^{3}$ Према Закону о заштити лица са менталним сметьама, 2013, чл. 2, ст. 1, т. 1, лице са менталним сметњама је недовољно ментално развијено лице, лице са поремећајима менталног здравља, односно лице оболело од болести зависности. 
да, ако се сматра да особа има умањену способност одлучивања, често услед когнитивних или психосоцијалних сметњи, његова или њена пословна способност да донесе одређену одлуку бива због тога укинута (Општи коментар, 2014, пар. 13). ${ }^{4}$ Пословна способност, наиме, према ставу Комитета, јесте урођено право свих људи, укључујући и особе са инвалидитетом, па, дакле, и менталним сметњама и стога им обе њене компоненте - правна способност и правно деловање (пословна способност) - морају бити признате како би право на пословну способност ових особа било остварено (Општи коментар, 2014, пар. 12бис). На крају, допуну ових ставова Комитета чини обавеза уздржавања од лишавања ових лица пословне способности, обезбеђење подршке (које мора уважавати права, вољу и склоности особа са инвалидитетом особама са инвалидитетом и не сме се претворити у заменско одлучивање) и приступ подршци (Општи коментар, 2014, пар. 14 и 15).

За разлику од Конвениије УН, Европска конвениија о заштити људских права и основних слобода, ${ }^{5}$ која је усвојена са циљем да обезбеди опште признање права и слобода и њихову заштиту, не помиње права посебних категорија или група лица, па ни инвалидних. Ипак, то да чл. 1 „свакоме” гарантује права и слободе предвиђене овом конвенцијом, као и став да Конвенщија УН не признаје посебна права особама са инвалидитетом, већ „реформулише” основна људска права и слободе (Mégret, 2008, p. 503-510), односно конкретизује обавезе држава уговорница у поштовању и стварању услова за једнако уживање постојећих људских права лицима са инвалидитетом, условљава директну везу повреде одредаба Европске конвенције и права ових лица. Стога је и Европски суд за људска права („ЕСЉП”) прихватио надлежност у низу предмета који се тичу повреде њихових људских права у контексту пословне способности.

\footnotetext{
${ }^{4}$ При томе, критикују се сва три приступа прихваћена у пракси: приступ заснован на статусу - одлука се доноси једноставно на основу дијагнозе оштећења, приступ заснован на исходу - уколико особа доноси одлуку за коју се сматра да има негативне последице и функционални приступ - када се вештине особе сматрају мањкавим (Општи коментар, 2014, пар. 13).

${ }_{5}^{5}$ Европска конвенијија о заттити људских права и основних слобода, CETS No. 005 („Европска конвенција”), усвојена је 1950. године у Риму, а у Републици Србији се примењује на основу Закона о ратификаиији Европске конвенщије о заштити људских права и основних слобода, Службени лист СЦГ - Међународни уговори, бр. 9 (2003), 5 (2005).
} 


\section{ЛИШЕЊЕ ПОСЛОВНЕ СПОСОБНОСТИ ЛИЦА СА МЕНТАЛНИМ СМЕТЬАМА И ПОСЛЕДИЦЕ ТАКВЕ ОДЛУКЕ}

Дефинишући пословну способност као универзално право, Конвенција УН инсистира на апсолутном уважавању аутономије лица са психосоцијалним и интелектуалним тешкоћама (Marković, 2012 , str. 73), односно на постојању претпоставке пословне способности или права на пословну способност. Као право, пословна способност не трпи изузетке, нпр. степен менталног инвалидитета (Lewis, 2011, p. 700-714), али је велики број лица управо из овог разлога лишен пословне способности и стављен под неки вид старатељства. Или, ментална сметња је најчешћи повод за лишавање пословне способности, а уједно и посебан основ за дискриминацију, с обзиром на то да се особи ускраћују права на основу личних карактеристика. Када се утврди постојање менталног дисабилитета, пословна способност је аутоматски под знаком питања, или, како се закључује у теорији, углавном се претпоставља одсуство способности особе да процени и схвати ситуације у којима се налази (Dhanda, 2007, p. 432). Овакав приступ има за последицу да се услови за лишење пословне способности директно доводе у везу са менталним сметњама, па такво лице мора доказивати супротно, што је изузетно тешко. Уз то, указује се и на забрињавајући системски аутоматизам у лишавању пословне способности лица са менталним сметњама, али и стереотипе и етикетирање у том смислу (Marković, 2012, str. 65; Петрушић, 2012, стр. 215). Неретко се, међутим, потпуно занемарују негативне последице одлуке о лишењу пословне способности. Дејства ове мере разликују се од државе до државе и крећу се од ограничења могућности закључења појединих правних послова, па до тзв. грађанске смрти - ускраћивања скоро свих основних људских права (Dinerstein, 2012, p. 9; Lawson, 2007, p. 563, 573).

О озбиљним последицама лишења пословне способности лица са менталним сметњама сведочи и пракса ЕСЉП, у оквиру које се могу издвојити одлуке у вези са нпр. одузимањем бирачког права лицима која су делимично лишена пословне способности (Alajos Kiss v. Hungary), затим смештање у установу социјалне заштите особа лишених пословне способности које траје дуги низ година без судске одлуке и без континуиране судске контроле оправданости и смисла присилног задржавања (Hadžimejlić and Others v. Bosnia and Herzegovina), неучествовање родитеља у поступку признања очинства услед лишења пословне способности (Krušković v. Croatia); немогућност учествовања особе лишене пословне способности у поступку усвајања детета ( $X$ v. Croatia) и сл. Потпуним или делимичним лишењем пословне способности спречава се у потпуности или ограничава учешће ових лица у правном промету, али и судским поступцима. Ова околност, као и њихова друштвена маргинализаци- 
ja, дискриминација повезана уз стигматизацију, а често и сиромаштво, за последицу има повреду људских права, па и у поступцима пред националним судовима.

На неприхватљиву праксу скоро аутоматског лишења пословне способности лица са утврђеним менталним сметњама (које постају једини основ за лишење), поред Комитета за права особа са инвалидитетом који прати примену Конвеничје $У Н$, указује и Комитет министара Савета Европе (Препорука Комитета министара Савета Европе бр. Р(99)4 о принципима везаним за правну заштиту одраслих особа са инвалидитетом, „Recommendation No. R(99)4”, Principle 2 - Flexibility in legal response, para. 4), односно да се мере за заштиту ових лица не смеју свести на рестрикцију пословне способности, нарочито не на њено аутоматско и потпуно одузимање. Лишење пословне способности могуће је и оправдано само као неопходна заштитна мера (Recommendation No. R(99)4, Principle 3 - Maximum preservation of capacity, par. 1). ${ }^{7}$ Ипак, бројни примери у пракси ЕСљП указују на то да недозвољена пракса лишавања пословне способности лица са менталним сметњама опстаје и када то није неопходно, односно оправдано.

\footnotetext{
${ }^{6}$ Република Србија има један од најрестриктивнијих закона у погледу материјалноправних услова за лишење пословне способности (Породични закон, 2005, чл. 146-147) и веома ригидну праксу. Иницијатива за права особа са менталним инвалидитетом анализирала је праксу судова у Србији у поступцима лишења пословне способности и поступцима преиспитивања постојања даљих разлога за лишење. Анализирано је укупно 699 решења о потпуном или делимичном лишењу прибављеним из 56 основних судова и 2 судске јединице (тражени подаци нису достављени из свих 66 основних судова и 29 судских јединица). У периоду од 1. 1. 2013. год. до 1. 1. 2016. год. било је 5280 поступака у којима се одлучивало о пословној способности, а чак 4739 лица потпуно или делимично је лишено пословне способности, што показује да је ова пракса и даље уобичајена и распрострањена. Најчешће се потпуно лишавају пословне способности лица са интелектуалним тешкоћама (40\%), а затим и са психосоцијалним (33\%) (Beker, Milošević, 2016, str. 29-32).

${ }^{7}$ И Препорука Комитета министара Савета Европе бр. Р(2004)10 у вези са заштитом људских права и достојанства особа са менталним поремећајем у чл. 4 предвиђа да лица са менталним поремећајима имају право да врше своја грађанска и политичка права, да ограничења у њиховом вршењу морају бити у складу са Европском конвенцијом, а искључиви основ ограничења не сме бити са̂м ментални поремећај.
} 


\section{ПРАВО НА СУДСКУ ЗАШТИТУ И ПРОЦЕСНОПРАВНЕ ГАРАНЦИЈЕ ЗА ЛИЦА СА МЕНТАЛНИМ СМЕТЬАМА У ПОСТУПКУ ЛИШЕЊА ПОСЛОВНЕ СПОСОБНОСТИ}

„Једнакост признања пред законом” (енгл. equal recognition before law) из члана 12 Конвенције УН односи се на сва лица и међународно право не познаје околности које би условиле лишење или ограничење овог права (Општи коментар, 2014, пар. 5). Наведена гаранција сматра се жилом куцавицом и самим језгром Конвениије УН (Tematski izveštaj, 2013, str. 23), а захтева, поред осталог, и укидање инвалидитета (по основу менталне сметње, нап. ауторки) као основа за лишење пословне способности, укидање праксе именовања старатеља који доноси одлуке у име лица са инвалидитетом и замену оваквог модела пружањем подршке лицима са инвалидитетом, тако да могу сами доносити (сопствене) одлуке (Monitoring the Convention on the Rights of Persons with Disabilities, Guidance for human Rights Monitors, Professional training series No. 17 (2010), p. 26). Овакав приступ мења и процесни положај лица са менталним сметњама у поступцима пред националним судовима, односно води признању њихових процесних права, па и у самом поступку у коме се одлучује о пословној способности ових лица. ${ }^{8}$ У контексту члана 13 , ст. 1 Конвенције УН, односно заштите процесних права особа са инвалидитетом, па и менталним, државе имају обавезу да овим лицима обезбеде ефикасан приступ правди равноправно са другима. Ипак, правни системи, како је већ наведено, способност за самостално предузимање процесних радњи признају, по правилу, особама којима грађанско материјално право признаје способност самосталног стицања права и обавеза, односно пословну способност (Познић, Ракић-Водинелић, 2015, стр. 199-202; Triva, Dika, 2004, str. 308). Стога је проблематичан процесни положај лица са менталним сметњама, односно њихова процесна овлашћења, и током поступка лишења пословне способности, имајући у виду да је њихова пословна способност доведена у питање, али је још увек нису лишени, нити им је она ограничена. Свакако, упитан је и процесни положај ових лица у судским поступцима након лишења или ограничења пословне способности, али на нешто другачији начин, односно у контексту обезбеђења њихове репрезентације у поступку (,заменско одлучивање" или подршка и помоћ у самосталном вршењу процесних

\footnotetext{
${ }^{8}$ У теорији се наводи да је у Републици Србији поступак лишења пословне способности ових лица сумаран и не гарантује поштовање права на правично суђење. Критеријуми за покретање поступка и доношење одлуке о одузимању пословне способности препознати су као нејасни и одлуку, суштински, доносе лекар и психолог који врше вештачење, а не судија. Нејасноће поступка дозивања у пракси воде и дискриминацији (Jovanović, 2014).
} 
дејстава). Обим рада не допушта анализу оба поменута аспекта, па ћемо се ограничити на први наведени, при чему се уопште мора поћи од става о нужности обезбеђења посебних процесних гаранција неопходних за правичан поступак (Tematski izveštaj, 2013, str. 27). На то упућује и ЕСЉП ставом да се „увођење посебних процесних гаранција може показати неопходним за заштиту права и интереса лица, која, услед менталних сметњи, нису у потпуности способна да их сама штите" (Winterwerp v. the Netherlands, §60; Vaudelle v. France, §60). Иако државе уговорнице имају одређено „поље слободне процене” када одлучују о процесним гаранцијама којима ће осигурати правично суђење, минималне гаранције прописане у члану 6 Европске конвенције морају бити примењене. Посебан значај поступка лишења условљава, наиме, не само законитост већ и „правичност” са аспекта Европске конвенције и праксе ЕСЉП (Shtukaturov v. Russia, §70; $X$ and $Y$ v. Croatia, §82).

Неспорно је да право на правично суђење подразумева право на приступ суду, иако га чл. 6 Европске конвениије не помиње изричито. Наиме, све чешће се и само право на правну, судску заштиту означава управо изразом „право на приступ суду” - access to justice (Познић, Ракић-Водинелић, 2015, стр. 69). Према ставу ЕСЉП, било би незамисливо да чл. 6, ст. 1 детаљно утврди процесне гаранције странака у поступку, а да прво не заштити оно што стварно омогућава корист од тих гаранција, што је приступ суду (нпр. Iordache $v$. Romania, §32-43; Enea v. Italy, §61-120; Mizzi v. Malta, §49-91). Оно је израз тежње да се заштити „право на добро спровођење правде” (Golder v. the United Kingdom, §33).

При томе, ЕСЉП препознаје бројне елементе права на приступ суду, између осталих, и право лица са менталним сметњама да покрене поступак лишења пословне способности (улогу суда у том смислу и специфичне гаранције), затим право да учествују у овом поступку, као и право на заступање у том поступку.

\section{Право лица са менталним сметьама да покрене и води поступак лишењ а пословне способности}

Право на приступ суду, у смислу права да се својим захтевом за заштиту обрати суду, има свако лице које (аргументовано) тврди да је задирање у остваривање његових (грађанских) права незаконито. Ипак, у настојању да ово право остваре, лица са менталним сметњама сусрећу се са бројним препрекама, које се своде на условљавање (или онемогућавање) приступа суду у поступцима који их се директно тичу. Тиме се доводи у питање сама суштина права на правично суђење које у сваком случају мора остати нетакнуто (Shtukaturov v. Russia, §68; Salontaji-Drobnjak v. Serbia, §133; Stanev v. Bulgaria, §230). 
Национална права, наиме, признају право на покретање поступка за лишење пословне способности, поред осталих, ${ }^{9}$ и лицима о чијој се пословној способности одлучује, али уз услов да могу да схвате значај и правне последице свог предлога. То је, уједно, и услов споран у теорији, с обзиром на то да се сматра нелогичним да неко ко је способан да схвати значај и правне последице предлога треба да буде лишен пословне способности, и то управо на сопствену иницијативу (Petrović, 2015).

Општи правни принципи водили би закључку да се лицу са менталним сметњама мора омогућити предузимање иницијалне радње, али и свих других радњи у поступку, с обзиром на то да је све до правноснажности одлуке о лишењу пословне способности (потпуном или делимичном) способно за њихово пуноважно предузимање. Ипак, ЕСЉП је у пракси заузео став да право на приступ суду није апсолутно и може бити предмет ограничења (Golder v. the United Kingdom, §38-39; Salontaji-Drobnjak v. Serbia, §133). Ипак, најважнији став ЕСЉП, у овом контексту, јесте да се право на приступ суду не сме потпуно укинути (Winterwerp v. the Netherlands, §75). Ограничења су, наиме, допуштена уколико су оправдана заштитом ових лица, интересом других или адекватним спровођењем правде (Nataliya Mikhaylenko v. Ukraine, §35). Она пак неће бити компатибилна са чланом 6 , ставом 1 ако не теже легитимном циљу и ако не постоји разуман однос пропорционалности између употребљених средстава и циља коме се тежи (Ashingdane v. the United Kingdom, §57).

У контексту права на приступ суду, односно, конкретније, права на иницирање поступка лишења пословне способности, међутим, мора бити поменуто и покретање поступка у коме се преиспитује стање лица којима је одузета или ограничена пословна способност. Наиме, периодична ревизија статуса лица са менталним сметњама и увођење одговарајућих и доступних правних средстава један је од најважнијих ставова које је ЕСЉП заузео у односу на успостављање процесних гаранција (Shtukaturov v. Russia; Sýkora v. the Czech Republic; Kędzior v. Poland; Mihailovs v. Latvia).

Значај одлука ЕСЉП у којима је разматран проблем процесних гаранција за лица са менталним сметњама, односно усвојених ставова у овим одлукама, условио је измене националних законодавстава у циљу поштовања формулисаних стандарда, па је тако одлука у случају Salontaji-Drobnjak v. Serbia довела до суштинских измена

\footnotetext{
9 Закон о ванпарничном поступку Републике Србије прописује (чл. 32, ст. 1 и 2) да поступак за лишење пословне способности покреће суд ex officio, као и на предлог органа старатељства, супружника, ванбрачног партнера, детета или родитеља лица које треба лишити пословне способности. Поступак се покреће и по предлогу деде, бабе, брата, сестре и унука, ако са тим лицем живе у породичној заједници.
} 
Закона о ванпарничном поступку Републике Србије. Између осталог, уведено је обавезно периодично разматрање стања подносиоца (3aкон о ванпарничном поступку, 2015, чл. 40, ст. 2).

\section{Учешће у поступку лишења пословне способности лиияа са менталним сметьама}

Сваком лицу се гарантује право учешћа у било ком процесу који би могао да утиче на његову пословну способност (Recommendation No. $\mathrm{R}(99) 4$, Principle 13 - Right to be heard in person). За лице са менталним сметњама учешће у поступку у којем се одлучује о његовој пословној способности од посебне је важности, јер је то прилика да буде саслушано и да се упозна са правима која му у складу са међународним документима и националним законом припадају. Иако лице са менталним сметњама има право да буде саслушано пред националним судом током поступка (подразумева се да је претходно обавештено о поступку и да је обезбеђено присуство тог лица), често се то не чини, што је, свакако, озбиљна повреда права на правично суђење ${ }^{10}$ Стога је ЕСЉП и заузео став да овим лицима мора бити омогућено учешће, с обзиром на његову двоструку улогу у поступку - као заинтересоване стране и као особе чија је пословна способност предмет одлучивања (Shtukaturov v. Russia, §72; Salontaji-Drobnjak v. Serbia, §127; A.N. v. Lithuania, §96). Осим фактичког учешћа, лицу које нема пун ментални капацитет треба омогућити да формира властито мишљење и да изрази своје ставове о свим питањима која се на њега односе, у мери у којој то допушта стање његовог здравља (Драшкић, 2010, стр. 369), односно очувани капацитети. Уз то, обавеза је националних власти да обезбеде и специфичне механизме за саслушање и да се ставовима, мишљењима и интересима ових лица посвети дужна пажња (Драшкић, 2010, стр. 369). То, даље, подразумева „не само да се том лицу омогући да представи свој случај већ и да судији омогући да формира своје мишљење о његовим менталним способностима" (Shtukaturov v. Russia, §72). ${ }^{11}$

\footnotetext{
${ }^{10} \mathrm{O}$ томе говоре и подаци у Републици Србији, односно да у $77,26 \%$ случајева суд или није саслушао странку или је одустао од саслушања, у $12,58 \%$ странка је саслушана, а у 10,16\% покушано је саслушање, али је констатовано да је странка неспособна. У чак $83 \%$ случајева, судија није током целокупног поступка лишавања пословне способности видео странку о чијој се пословној способности одлучује (Gajin \& Vlahović, 2014).

${ }^{11}$ Треба имати у виду да лице о чијој се пословној способности одлучује има право да буде саслушано, али да то није његова дужност. Да ли ће се одазвати позиву суда и да ли ће на рочишту бити активно или пасивно - искључиво зависи од његове воље. Суд није овлашћен да нареди његово принудно довођење, нити га може принудити на давање исказа, јер то закон не допушта (Petrušić, Beker, Ćirić Milovanović, 2016, str. 52-62).
} 
Дакле, ЕСЉП је изричит у ставу да судија мора имати лични контакт са лицем о чијој се пословној способности одлучује ( $X$ and $Y$ v. Croatia, $\S 84)$, односно неприхватљивим сматра да се одлука о лишењу пословне способности доноси само на основу писаних доказа, ${ }^{12}$ без личног сусрета или саслушања тог лица. ${ }^{13}$

Ставови ЕСЉП суштински се своде на инсистирање да се поштује право на партиципацију, као темељно људско право, па и особа које се лишавају пословне способности (и не само у поступцима лишења). ${ }^{14}$ Учешће у поступку је претпоставка контрадикторног расправљања, с обзиром на то да странкама омогућава да оспоравају чињеничне тврдње и доказе и тиме доприносе утврђивању истине. Ипак, ЕСЉП не заступа доследно овакав став. Тако, у случају Berková v. Slovakia, национални суд није лично саслушао подноситељку представке (већ „само” лекара-вештака, именованог заступника и представника локалне власти), нити је она обавештена о одлуци да је лишена пословне способности, па није могла поднети жалбу.

12 ЕСЉП посебно разматра да ли медицинска документација има доминантан утицај на одлучивање у поступцима који се тичу пословне способности лица са менталним сметњама и закључује да свака одлука мора бити поткрепљена релевантном и актуелном медицинском документацијом. Тако је у одлуци H.F. v. Slovakia ЕСЉП утврдио повреду члана 6, става 1 због тога што је, поред других пропуста у поступку, национални суд пропустио да изведе довољно доказа сходно начелу 12 Препоруке R(99)4 (Recommendation No. R(99)4, Principle 12 Investigation and assessment), према којем се захтева „најмање један новији, актуелан (up-to-date) извештај о стању пунолетне особе сачињен од стране стручњака одређене струке". У овом случају ЕСЉП је установио да изјаве бившег супруга подноситељке представке и „обичних” сведока, којима је придодат лекарски налаз стар више од годину и по дана (где је једна од подноситељки била само 20 минута предмет пажње психијатра, и то у време када је била под дејством медикамената), нису представљали довољне доказе за лишавање пословне способности. И у одлуци $X$ and $Y v$. Croatia (§85) ЕСЉП истиче неопходност свеобухватног психијатријског прегледа. Ипак, децидан је став ЕСЉП да одлуку доноси судија, а не лекар чије извештаје национални судови често некритички узимају као основ за своје одлуке. Национални суд мора ценити све околности везане за то лице и са посебном пажњом настојати да успостави равнотежу између свих релевантних фактора за одлучивање о мери која је пропорционална.

13 У случају Salontaji-Drobnjak v. Serbia $(\$ 48)$ наводи се да је национални суд у одлуци којом се подносилац представке делимично лишава пословне способности заузео став да „нема потребе да се подносилац представке лично саслуша пошто то, на основу доступних психијатријских доказа, није целисходно”. И у случају D.D. v. Lithuania као „непотребно” је наведено учешће подноситељке представке (лица са менталном сметњом) у поступку, па она није била присутна на расправи нити консултована, односно укључена у одређивање старатеља (\$44).

${ }^{14}$ Типичан је, у овом смислу, став ЕСЉП у случају $X$ v. Croatia (§53) да се „тешко може прихватити чињеница да свака особа лишена пословне способности треба аутоматски да буде искључена из поступка усвојења свог детета", те да је „било потребно пружити јој прилику да буде саслушана”. 
ЕСЉП је (ипак) закључио да је било довољно доказа за поуздано утврђивање чињеница, као и да је било довољно процесних гаранција за заштиту њених права и интереса (Berková v. Slovakia, §149-151). Уз то, одступање од става да је лично учешће неопходно ЕСЉП није ни образлагао у одлуци, па се у теорији оправдано истиче да се тиме „ствара одређена несигурност у лаганом, али позитивном напредовању - од ускраћивања до једнаких права на учешће у поступку особама са инвалидитетом" (Knol Radoja, 2015, str. 951).

Напоменимо да је изменама нашег Закона о ванпарничном поступку потенцирана обавеза суда да лично саслуша (,суд ће лично саслушати") лице о чијој се пословној способности одлучује, али и формулисан став да судија „уважава мишљења и ставове” ових лица у „мери у којој је то могуће с обзиром на стање његовог менталног здравља". ${ }^{15}$

\section{Заступање лииа са менталним сметњама у поступку лишења пословне способности}

ЕСЉП је у својој пракси, разматрајући право лица са менталним сметњама да учествују у поступку у коме се одлучује о њиховој пословној способности, поред личног, непосредног учешћа, прихватио и могућност учешћа на други начин, нпр. кроз неки облик заступања ( $X$ v. Croatia, §61; Winterwerp v. the Netherlands, §60; Shtukaturov v. Russia, §71; D.D. v. Lithuania, §118). При томе се постављање заступника не прихвата prima facie као поштовање једне од основних процесних гаранција потпуне једнакости пред законом и у поступку. „Независно правно заступање” је стандард који се, при томе, мора поштовати. ${ }^{16}$ Наиме, положај лица са менталним сметњама често у потпуности зависи од стараоца одређеног по службеној дужности, а који заступање не врши адекватно. Стараоци су најчешће лица блиска штићенику (супружник, сродник) и неквалификована за предузимање процесних радњи, па ни у поступцима који се тичу пословне способности. Стога је заступање лица са менталним сметњама формално и не обезбеђује заштиту права и интереса ових лица (Петрушић, 2015, стр. 916).

Став ЕСЉП је да су државе дужне да лицима са менталним сметњама осигурају независно заступање, које ће им омогућити да

\footnotetext{
15 Закон о ванпарничном поступку, 2015, чл. 36.

${ }^{16}$ Примена независног правног заступања у поступцима чији је циљ стављање под старатељство пунолетне особе има основ у Принципу 7 Препоруке R(99)4 (Recommendation No. R(99)4, Principle 7 - Procedural fairness and efficiency, par. 2), који формулише да „током поступка треба да постоје одговарајуће гаранције за заштиту људских права пунолетне особе којима би се спречиле могуће злоупотребе".
} 
њихове приговоре испита суд или друго независно тело (Ivinović v. Croatia, §45; Centre for Legal Resources on behalf of Valentin Câmpeanu v. Romania, §161; Stanev v. Bulgaria, §258). При томе се адвокат, као квалификовани заступник, чини најадекватнијим решењем. Примена оваквог механизма морала би, заправо, подразумевати дужност суда да лицу о чијој се пословној способности одлучује постави заступника, па и бесплатног, ако лице нема средстава да га плати, јер је то гаранција да ће право на контрадикторан поступак бити делотворно, а са̂м поступак испунити стандарде правичности (Петрушић, 2015, стр. 916). Исти принцип важио би и у ситуацији када постоји сукоб интереса између овог лица и старатеља (који се нпр. противи укидању мере лишења пословне способности) (Knol Radoja, 2015, str. 945). У случају D.D. v. Lithuania национални суд је одбио изричит захтев подноситељке представке да јој се обезбеди независна правна помоћ уз образложење да је већ заступа адвокат њеног старатеља, што подноситељка сматра недопуштеним имајући у виду конкурентске интересе. У овим околностима, подноситељка је, као лице лишено пословне способности, била онемогућена да на било који начин утиче на поступак, стога што упркос поседовању финансијских средстава за ангажовање пуномоћника није могла њима располагати. Јасно је да постојање оваквог сукоба може значајно утицати на права и интересе штићеника. ${ }^{17}$

Пракса ЕСЉП показује и да је један од стандарда правичног суђења у односу на лица о чијој се пословној способности одлучује или им је она већ одузета или ограничена обезбеђење асистенције преко квалификованих особа како би могле изразити своју вољу (жеље, ставове, мишљења), а у циљу ефективног приступа суду и водећи рачуна о сложености предмета и поступка, значају правне ствари и могућим последицама поступка (M.S. v. Croatia, §104), као и финансијској ситуацији лица.

\footnotetext{
17 За разлику од тога, важећи прописи у Републици Србији не омогућавају да се особи о чијој се пословној способности одлучује постави адвокат бесплатно, чак и када она то изричито тражи, јер се, сагласно Закону о парничном поступку, 2011, чл. 170 , који се у ванпарничном поступку сходно примењује, адвокат бесплатно може поставити само странци која је ослобођена претходног плаћања трошкова поступка, а у поступку за лишење пословне способности особа према којој се поступак води не сноси трошкове, па се ова одредба не може применити (Петрушић, 2015, стр. 917).
} 


\section{ЗАКЉУЧАК}

Лишење пословне способности је крајња и рестриктивна мера која условљава изузетно озбиљне последице. Имајући у виду значај такве одлуке, неопходно је да буду испуњене претпоставке правичног суђења, које се, пре свега, односе на то да лицима са менталним сметњама буде обезбеђено поштовање права на судску заштиту из члана 6 , које подразумева право лица са менталним сметњама да покрене и води поступак лишења пословне способности, затим лично учешће у поступку (не само омогућавањем присуства и саслушања у поступку већ и механизмима који ће гарантовати да таква лица формулишу и изразе лични став, када год је то и колико год је то могуће с обзиром на очувани ментални капацитет), али и гаранцијама у односу на адекватно заступање. Сви ови захтеви успостављени су у циљу највишег степена заштите права и интереса таквих лица. Уколико ове гаранције, као елементи права на правично суђење, нису нормативно уређене и стварно примењене, онда то најчешће води кршењу основних права лица са менталним сметњама. О томе се закључује и из праксе ЕСЉП, односно његовог јасног става да менталне сметње не смеју утицати на поштовање правичног суђења гарантованог чланом 6, ставом 1 Европске конвенщије у свим његовим аспектима, али и да национални судови морају овим лицима обезбедити посебне процесне гаранције. Поред тога, и са̂м поступак у коме се одлучује о лишењу пословне способности треба спроводити само у изузетним случајевима (односно постојање менталне сметње не може бити једини разлог на којем се заснива судска одлука о лишењу или ограничењу пословне способности), онда када се циљ - заштита ових категорија лица - не може постићи мање репресивним мерама, па се решење можда налази у „промени парадигме” по питању ове врсте инвалидитета, која се често описује као промена у начину на који се посматрају лица са инвалидитетом, од објекта ка субјекту (Tematski izveštaj, str. 17), односно напуштање овог анахроног приступа.

\section{ЛИТЕРАТУРА}

Beker, K., Milošević, T. (2016). Poslovna sposobnost - Sudska praksa i zakoni u Srbiji 2016. godine [Legal capacity - jurisprudence and laws in Serbia in 2016.]. Beograd. Inicijativa za prava osoba sa mentalnim invaliditetom MDRI-S.

Dhanda, A. (2007). Legal Capacity in the Disability Rights Convention:Stranglehold of the Past or Lodestar for the Future?. Syracuse Journal of International Law and Commerce, 2, 429-462.

Dinerstein, R. (2012). Implementing Legal Capacity Under Article 12 of the UN Convention on the Rights of Persons with Disabilities: The Difficult Road From Guardianship to Supported Decision-Making. Human Rights Brief, 2, 8-12. 
Gajin, S., \& Vlahović, S. (Ur.). (2014). Prava osoba sa mentalnim invaliditetom [The rights of persons with mental disabilities], Knjiga II: Pravni položaj u društvu Beograd: Centar za unapređenje pravnih studija

Jovanović, M. (2014). Pravni položaj osoba sa invaliditetom [The legal status of persons with disabilities], Peščanik.net, http://pescanik.net/pravni-polozajosoba-sa-invaliditetom-2/.

Knol Radoja, K. (2015). Povreda procesnih prava osoba s invaliditetom [Violation of the procedural rights of persons with disabilities]. Zbornik Pravnog fakulteta $u$ Zagrebu, 6, 931-954.

Kos, M. (2014). Lud, zbunjen, političan i subject [Crazy, confused, politically minded and subject], JAHR - European Journal of Bioethics, 9, 211-221.

Lawson, A. (2007). The United Nations Convention on the Rights of Persons with Disabilities: New era or false dawn?. Syracuse Journal of International Law and Commerce, 2, 563-575.

Lewis, O. (2011). Advancing Legal Capacity Jurisprudence. European Human Rights Law Review, 6, 700-714.

Marković, M. (2012). Poslovna sposobnost kao univerzalno ljudsko pravo i determinanta društvenog položaja lica sa mentalnim invaliditetom [Legal capacity as a universal human right and a determinant of social status of people with mental disability], Stanovništvo, 2, 65-83.

Mégret, F. (2008). The Disabilities Convention: Human rights of persons with disabilities or disability rights?. Human Rights Quarterly, 30, 494-516.

Opšti komentar člana 12 Konvencije o pravima osoba s invaliditetom [The General Comment on Article 12 of the Convention on the Rights of Persons with Disabilities], Komitet za prava osoba s invaliditetom UN-a, 2014.

Petrović, J. (2015). Sporna pitanja kod postupka lišenja poslovne sposobnosti [Contentious issues in the cases of deprivation of legal capacity], http://www. pravniportal.com/sporna-pitanja-kod-postupka-lisenja-poslovnesposobnosti/

Petrušić, N., Beker, K., Ćirić Milovanović, D. (2016). Smernice za postupanje sudija u slučajevima lišavanja poslovne sposobnosti [Guidelines for the conduct of judges in cases of deprivation of legal capacity]. Inicijativa za prava osoba sa mentalnim invaliditetom MDRI-S, Beograd, http://www.mdri-s.org/wpcontent/uploads/2017/01/Smernice-za-sudije.pdf

Tematski izveštaj Komesara Saveta Evrope za ljudska prava, Pravo na poslovnu sposobnost lica sa intelektualnim i psihosocijalnim invaliditetom - Ko može da odlučuje [Right to legal capacity for persons with intellectual and psychosocial disabilities - Who gets to decide?], 2013, https://www.coe.int/t/ commissioner/source/prems/IP_LegalCapacity_serb.pdf

Triva, S., Dika, M. (2004). Građansko parnično procesno pravo [Civil lawsuit procedural law], Zagreb: Narodne novine.

World Health Organization. World Report on Disabilitiy (2011), http://www.who.int/ disabilities/world_report/2011/report.pdf.

Драшкић, М. (2010). Нови стандарди за поступак лишења пословне способности: актуелна пракса Европског суда за људска права [New Standards in the Proceedings for Deprivation of Active Legal Capacity: Actual Case-Law of the European Court of Human Rights], Анали Правног факултета у Београду, 2, 355-370.

Мониторинг Конвенције о правима особа са инвалидитетом, Упутство за мониторе за људска права, Серија професионалних обука бр. 17 (2010) [Monitoring the Convention on the Rights of Persons with Disabilities, Guidance for human Rights Monitors, Professional training series No. 17 
(2010)]. Office of the United Nations High Commissioner for Human Rights, New York and Geneva.

Петрушић, Н. (2015). Поступак за лишење пословне способности у праву Србије у контексту међународних стандарда о правима особа са инвалидитетом [Procedure for deprivation of legal capacity in Serbia in the context of international standards on the Rights of Persons with Disabilities]. Зборник радова Правног факултета у Нишу, 70, 903-920.

Петрушић, Н. (Ур.). (2012). Судска грађанскоправна заштита од дискриминације [Judicial civil protection against discrimination]. Београд: Повереник за заштиту равноправности и Правосудна академија.

Познић, Б., Ракић-Водинелић, В. (2015). Грађанско прочесно право [Civil procedural law], Београд: Правни факултет Универзитета Унион у Београду и ЈП Службени гласник.

\section{ПРАВНИ ИЗВОРИ}

Препорука Комитета министара Савета Европе бр. Р(2004)10 у вези са заштитом људских права и достојанства особа са менталним поремећајем [Council of Europe, Recommendation Rec(2004)10 of the Committee of Ministers to Member States concerning the protection of human rights and dignity of persons with mental disorder]

Препорука Комитета министара Савета Европе бр. Р(99)4 о принципима везаним за правну заштиту одраслих особа са инвалидитетом [Council of Europe, Recommendation No. R(99)4 of the Committee of Ministers to Member States on principles concerning the legal protection of incapable adults]

Закон о ванпарничном поступку [Law on Extra-Judicial Procedure of the Republic of Serbia], Службени гласник РС. Бр. 106 (2015)

Закон о заштити лица са менталним сметњама [Law on Protection of Person with Mental Disabilities], Службени гласник РС. Бр. 45 (2013)

Закон о парничном поступку [Civil Procedure Law], Службени гласник PC. Бр. $72(2011)$

Закон о потврђивању Конвенције о правима особа са инвалидитетом [Law on the ratification of the Convention on the Rights of Persons with Disabilities], Службени гласник РС - Међународни уговори. Бр. 42 (2009)

Европска конвенција о заштити људских права и основних слобода [European Convention for the Protection of Human Rights and Fundamental Freedoms], Савет Европе, CETS No.005, (1950)

Закон о ратификацији Европске конвенције о заштити људских права и основних слобода [Law on the ratification of the European Convention for the Protection of Human Rights and Fundamental Freedoms], Службени лист СЦГ Међународни уговори. Бр. 9 (2003), 5 (2005)

Конвенција о правима особа са инвалидитетом [Convention on the Rights of Persons with Disabilities], УH - A/RES/61/106, (2006)

Породични закон [Family Act], Службени гласник РС. Бр. 18 (2005)

\section{ОДЛУКЕ ЕВРОПСКОГ СУДА ЗА ЉУДСКА ПРАВА}

A.N. v. Lithuania, No. 17280/08 од 31. маја 2016.

Alajos Kiss v. Hungary, №. 38832/06 од 20. маја 2010.

Ashingdane v. the United Kingdom, №. 8225/78 од 28. маја 1985. 
Berková v. Slovakia, №. 67149/01 од 24. марта 2009.

Centre for Legal Resources on behalf of Valentin Câmpeanu v. Romania, No.47848/08 од 17. јула 2014.

D.D. v. Lithuania, No.13469/06 од 14. фебруара 2012.

Enea v. Italy, №. 74912/01 од 17. септембра 2009.

Golder v. the United Kingdom, №. 4451/70 од 21. фебруара 1975.

H.F. v. Slovakia, No. 54797/00 од 8. новембра 2005.

Hadžimejlić and Others v. Bosnia and Herzegovina, No. 3427/13, 74569/13 and 7157/14 од 3. новембра 2015.

Iordache v. Romania, №. 6817/02 од 14. октобара 2008.

Ivinović v. Croatia, No.13006/13 од 18. септембра 2014.

Kędzior v. Poland, No. 45026/07 од 16. октобра 2012.

Krušković v. Croatia, No. 46185/08 од 21. јуна 2011.

M.S. v. Croatia, №. 36337/10 од 25. априла 2013.

Mihailovs v. Latvia, No. 35939/10 од 22. јануара 2013.

Nataliya Mikhaylenko v. Ukraine, No. 49069/11 од 30. маја 2013.

Mizzi v. Malta, No. 26111/02 од 12. јануара 2006.

Salontaj-Drobnjak v. Serbia, No. 36500/05 од 13. октобра 2009.

Shtukaturov v. Russia, No. 44009/05 од 27. марта 2008.

Stanev v. Bulgaria, №. 36760/06 од 17. јануара 2012.

Sýkora v. the Czech Republic, No. 23419/07 од 22. новембра 2012.

Vaudelle v. France, No. 35683/97 од 30. јануара 2001.

Winterwerp v. the Netherlands, No. 6301/73 од 24. октобра 1979.

$X$ and $Y$ v. Croatia, No.5193/09 од 3. новембра 2011.

$X$ v. Croatia, No.11223/02 од 17. јуна 2008.

\title{
SOME ASPECTS OF RIGHT ON JUDICIAL PROTECTION OF PERSONS WITH MENTAL DISIBILITIES IN THE PROCEDURES FOR DEPRIVATION OF LEGAL CAPACITY - PRACTICE OF THE EUROPEAN COURT OF HUMAN RIGHTS
}

\author{
Dušica Palačković ${ }^{1}$, Sanda Ćorac ${ }^{2 *}$ \\ ${ }^{1}$ University of Kragujevac, Faculty of Law, Kragujevac, Serbia \\ ${ }^{2} \mathrm{Niš}$, Serbia
}

\begin{abstract}
Summary
Deprivation of legal capacity is an ultimate and restrictive measure that causes extremely serious consequences (it range from the limitation the possibility of concluding certain legal affairs to the so-called "civic death", i.e. the denial of almost all basic human rights). Persons with mental disibilities in the procedures for deprivation of legal capacity have numerous of problems, regardless of the normative framework, both international and national, which largely protects the rights of this group of people.Considering the fact that the judicial procedures in which a legal capacity is decided about most directly affects the civil rights of a particular person, consequently the safeguards of fair trial under Article 6, para.1 of the European Convention must be respected.The preconditions for a fair trial are primarily related to ensuring that persons
\end{abstract}


with mental disabilities are entitled the right to initiate and conduct the procedures for deprivation of legal capacity (since it's up to the decision for deprivation of capacity person is capable of being validly undertaken), then personally participate in the procedures (not only by facilitating the presence and hearing in the procedures, but also by mechanisms that will guarantee that these persons will formulate and express their personal standpoint whenever and wherever possible, considering preserved mental capacity), but also safeguards in relation to the adequate representation in this procedures (which should be regarded as a basic procedural safeguard to ensure full equality before the law and in the procedures). All these requests have been established in order to achieve the highest degree of protection of the rights and interests of persons with mental disabilities. If these safeguards, as elements of the right to a fair trial, are not normatively regulated and actually applied, this most often leads to a violation of the basic rights of persons with mental disabilities. This also follows from the practice of the ECtHR, i.e. it's defined attitude that mental disabilities must not affect the fair trial guaranteed under Article 6, para. 1 of European Convention in all its aspects, but also that national courts must provide to these persons the specific procedural safeguards in the proce for deprivation of legal capacity. Besides, the standpoint in court practice, but also in theory, is that the procedures for deprivation of legal capacity should be carried out only in exceptional cases (the existence of mental disability can't be the only reason on which the court decision of deprivation or limitation of legal capacity is based), i.e. the emphasis is on the efforts to achieve the protection of these persons with less repressive measures. 